\title{
ARTICLE
}

\section{Stability of Vitamin C in Enriched Jelly}

\author{
Lucile Tiemi Abe-Matsumoto* $\triangle$ Yara Alves de Araújo, Magda Leite Medeiros \\ Núcleo de Química, Física e Sensorial, Centro de Alimentos, Instituto Adolfo Lutz, Avenida Dr. Arnaldo, 355, \\ Pacaembu, CEP: 01246-000, São Paulo, SP, Brazil
}

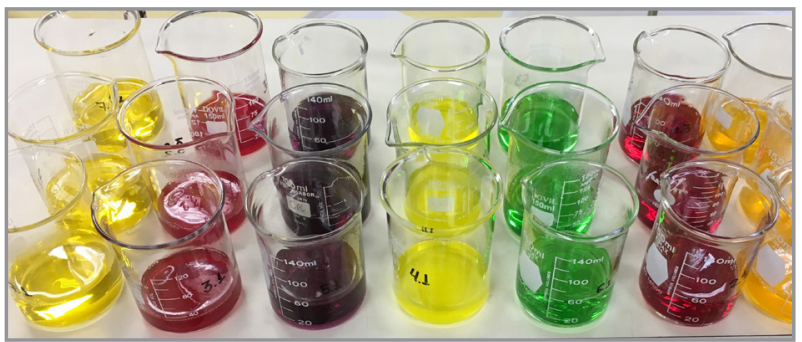

Fortification of foods with vitamins has become increasingly common. However, further studies on the stability of vitamins in foods are required because these compounds can easily degrade. The objective of this study was to evaluate the stability of ascorbic acid (AA; vitamin $\mathrm{C}$ ) in fortified gelatin after dissolving the powder in water at room temperature $\left(25^{\circ} \mathrm{C}\right)$, after preparing the jelly according to label instructions, and after storing the ready-to-eat product for three days in the refrigerator, comparing the obtained values to those stated on the label. AA was measured by iodometry using an automatic potentiometric titrator with a platinum ring electrode. The AA contents of all the samples dissolved in cold water were either equal to or above those stated on their labels. However, the AA contents of two of the prepared and stored samples were below their stated label values, confirming AA degradation.

Keywords: Gelatin, vitamin, ascorbic acid, stability, potentiometry.

\section{INTRODUCTION}

Gelatin is a protein product derived from partial hydrolysis of animal collagen, which is present in bones and skin and is obtained primarily from pigs and cattle. It is extracted by acid or alkaline hydrolysis, then purified and concentrated [1]. All types of gelatin have similar compositions and contain water, a small amount of mineral salts, and connective tissue protein. However, depending on the raw material, type of pretreatment, and rate of hydrolysis, various types of gelatin, having different properties, can be obtained for different purposes. Gelatin is widely used in the food industry to improve the elasticity, consistency, and stability of food products. It is also used as a fat substitute, particularly in dairy products, to reduce the caloric contents of various foods without significantly affecting their taste [2]. Fruit-flavoured gelatin desserts are popular in Brazil. These products are easily prepared, inexpensive, and highly accepted by consumers of various age groups. Therefore, gelatin can be supplemented with micronutrients to provide more nutritious foods to consumers, in view of the inadequate intake of vitamin $\mathrm{C}$ by the Brazilian population [3]. Several industrialised foods, such as cookies, cakes, bread, and desserts, are fortified with vitamins to increase their nutritional, commercial, and market value.

Resolution RDC N ${ }^{\circ}$ 54/2012 of Brazilian Health Regulatory Agency of the Ministry of Health (ANVISA/ MS) established that the use of complementary nutritional information, such as "vitamin source" and "vitamin rich", on food labels is allowed, provided that the foods contain respectively, 15 or $30 \%$ of the

Cite: Abe-Matsumoto, L. T.; de Araújo, Y. A.; Medeiros, M. L. Stability of Vitamin C in Enriched Jelly. Braz. J. Anal. Chem., 2020, 7 (27), pp 14-19. doi: http://dx.doi.org/10.30744/brjac.2179-3425.AR-38-2019 
recommended daily intake of the said micronutrient in $100 \mathrm{~g}$ or $100 \mathrm{~mL}$ of ready-to-eat product or serving [4]. Foods fortified with ascorbic acid (AA; vitamin $C$ ) have increased acceptance by consumers as there is scientific evidence supporting the benefits of consuming this micronutrient, including improvement of immune function, increased absorption of iron from the product, and/or antioxidant properties [5].

Different methods have been used for the determination of vitamin C in foods, including spectrophotometry, electrophoresis, voltammetry, titration, and high performance liquid chromatography (HPLC) [6-8]. The iodometric titration for vitamin $\mathrm{C}$ determination is the official method of Adolfo Lutz Institute, a Central Public Health Laboratory of Sao Paulo State. In this method, the iodine reacts with vitamin C, and the endpoint of the titration is determined by the first excess of iodine in the solution, that reacts with the starch indicator, forming a complex with an intense dark blue-violet color [9]. This method is single, fast, and reliable, however, the endpoint of the titration cannot be easily detected when the sample has intense color, such as gelatin. The alternative to excluding color interference was to transfer the traditional iodometric titration to automatic potentiometric titrator, as performed in this work, in which the endpoint of the titration is indicated by platinum ring electrode, and no color interference occurs.

Since iodine solution $\left(\mathrm{I}_{2}\right)$ is highly unstable to be used as a titrant, the present method is based on the reaction of potassium iodide $(\mathrm{KI})$ with potassium iodate $\left(\mathrm{KIO}_{3}\right)$ titrant solution, in acidic medium $\left(\mathrm{H}_{2} \mathrm{SO}_{4}\right)$ releasing $\mathrm{I}_{2}$ (Equation 1) which reacts with $\mathrm{AA}$ (Equation 2) [9].

$$
\begin{array}{ll}
5 \mathrm{KI}+\mathrm{KIO}_{3}+3 \mathrm{H}_{2} \mathrm{SO}_{4} \rightarrow 3 \mathrm{I}_{2}+3 \mathrm{~K}_{2} \mathrm{SO}_{4}+3 \mathrm{H}_{2} \mathrm{O} & \text { (Equation 1) } \\
\mathrm{C}_{6} \mathrm{H}_{8} \mathrm{O}_{6}(\mathrm{AA})+\mathrm{I}_{2} \rightarrow \mathrm{C}_{6} \mathrm{H}_{6} \mathrm{O}_{6}+2 \mathrm{HI} & \text { (Equation 2) }
\end{array}
$$

Several physical and chemical factors can affect the stability of vitamins, including temperature, humidity, oxygen, light, $\mathrm{pH}$, oxidizing and reducing agents, presence of metal ions, and/or other ingredients in the matrix [10]. Since AA is highly unstable, it is crucial to determine its concentration during food preparation and storage, especially in gelatin products, which involves heating during preparation.

The objective of this study was to evaluate the stability of AA-fortified gelatin by determining the AA content after dissolving the powder in cold water, immediately after preparation according to the manufacturer's instructions, and after storing the ready-to-eat product for three days in the refrigerator. An assessment was also made as to whether AA concentrations before and after storage agreed with the values stated on the nutritional information label.

\section{MATERIALS AND METHODS \\ Samples}

Eight gelatin powder samples containing nutritional information regarding fortification concentrations of AA were locally purchased in São Paulo, Brazil.

\section{Standards and reagents}

L-ascorbic acid ( $\geq 99.9 \%$ ) were purchased from Sigma-Aldrich (St Louis, MO, USA). Analytical-grade reagents sulfuric acid $\left(\mathrm{H}_{2} \mathrm{SO}_{4}\right)$, potassium iodide $(\mathrm{KI})$, and potassium iodate $\left(\mathrm{KIO}_{3}\right)$ were purchased from Synth (Sao Paulo, Brazil).

\section{Determination of $A A$}

AA concentrations were evaluated at three stages: Stage 1) after dissolving the gelatin powder in water at room temperature $\left(25^{\circ} \mathrm{C}\right)$; Stage 2) immediately after preparation according to the manufacturer's instructions $\left(95^{\circ} \mathrm{C}\right)$; and Stage 3 ) after storing the product in a refrigerator $\left(4-6{ }^{\circ} \mathrm{C}\right)$ for three days, which simulated domestic consumption and met the expiration date recommendations described on the package label. AA concentrations were determined by iodometry using an automatic potentiometric titrator with a Tiamo $^{\circledR}$ software-controlled platinum ring electrode (Metrohm Pensalab, Herisau, Switzerland) [6]. For 
each sample, the gelatin powder from the same package (stages 1, 2, and 3) equivalent to 5-10 mg of AA content was weighed in a $150 \mathrm{~mL}$ beaker. Samples of stage 1 analysis were dissolved in water at room temperature $\left(25^{\circ} \mathrm{C}\right)$, while samples of stage 2 and 3 were first dissolved in water at $95^{\circ} \mathrm{C}$, and then cold water was added, proportionally, according to method of preparation on the label. Stage 1 and 2 analyses were performed as soon as the dissolution was complete, and stage 3 analysis, after 3 days stored in a refrigerator. For the titration procedure, $10 \mathrm{~mL}$ of $20 \%(\mathrm{v} / \mathrm{v})$ sulfuric acid $\left(\mathrm{H}_{2} \mathrm{SO}_{4}\right)$ and $1.0 \mathrm{~mL}$ of $10 \%(\mathrm{v} / \mathrm{v})$ potassium iodide $(\mathrm{KI})$ were added to the beaker, and the sample was titrated with $0.002 \mathrm{M}$ potassium iodate $\left(\mathrm{KIO}_{3}\right)$. Each $\mathrm{mL}$ of the $\mathrm{KIO}_{3}$ solution used in the titration was equivalent to $0.8806 \mathrm{mg}$ of $\mathrm{AA}$. The data was transferred to Excel spreadsheets, and the results were analysed using Tiamo Software and expressed in mg of AA per serving.

Validation of the titrimetric method for vitamin $\mathrm{C}$ was carried out according to the guidelines of the International Conference on Harmonisation (ICH) [11]. For the gelatin matrix, the recovery test was performed using recovered standards of AA spiked in gelatin at three concentration levels and three replicates.

A standard $\mathrm{AA}$ solution (concentration $=1.0 \mathrm{mg} \mathrm{mL}^{-1}$ ) was used as an internal control. Titrations with 10 $\mathrm{mL}$ of this solution were performed in triplicate. Resulting AA contents of $10 \pm 0.15 \mathrm{mg}$ indicated that the performance of the method is satisfactory.

\section{Data analysis}

The results were expressed in terms of means and standard deviations $(n=3)$. The one-way analysis of variance (ANOVA) and Tukey's multiple comparison test was used to differentiate between the means of the vitamin $C$ content $(p<0.05)$ determined in three steps. All statistical analyses were conducted using Microsoft Excel for Windows ${ }^{\circledR} 10$ (Microsoft Corporation, Redmond, WA, USA, 2010) and Action Software (Estatcamp, 2014). The level of statistical significance was set at $5 \%$ for all analyses [12].

\section{RESULTS AND DISCUSSION Vitamin C stability}

The validation parameters for titrimetric method for determination of vitamin $\mathrm{C}$ are reported in Abe-Matsumoto et al [13]. The LOD and LOQ is $1.0 \mathrm{mg}$ and $3.0 \mathrm{mg}$, respectively [13]. Recovery (\%) for the gelatin matrix ranged from $97.2 \%$ to $100.7 \%$, where the results (\%) of triplicate for each level $(1,2$ and 3$)$ were respectively $98.5 \pm 1.9$, $99.2 \pm 0.5$, and $99.2 \pm 0.6$, and was considered satisfactory according to $\mathrm{ICH}$ [11].

The AA concentrations stated on the nutritional information labels of the samples ranged from 8.1 to $16.0 \mathrm{mg}$ per $120 \mathrm{~g}$ of product. Resolution RDC N ${ }^{\circ} 360 / 2003$ of ANVISA/MS allows a difference of up to $20 \%$ of the value stated on the label [14]. AA concentrations in the powder samples dissolved in water at room temperature $\left(25^{\circ} \mathrm{C}\right.$ ) were either below or equal to $20 \%$ tolerance allowed by the legislation (samples $D$ and $E$ ) or above this limit (samples $A, B, C, F, G$, and $H$ ), indicating that the manufacturers fortified the products. After preparation according to the manufacturer's instructions, AA was highly degraded in two of the samples ( $C$ and $D)$. After refrigerating the products for three days, AA was significantly degraded in three of the samples (A, C, and D), with the concentrations in two of these samples (C and $D)$ were below those stated on their labels, and four of the samples (A, F, G, and H) had concentrations above $20 \%$ tolerance limit.

AA is easily oxidized even when stored in a refrigerator, which decreases its nutritional value. Phillips et al. [15] found that the loss of AA content in vegetable samples frozen for 12 months at $-60^{\circ} \mathrm{C}$ ranged from 13.7 to $26.0 \%$. However, AA was not degraded during the storage of tangerine juice under the same conditions, probably because of the high acidity of this fruit contributing to the compound's stability [15]. Antioxidant vitamins found in supplements, including vitamin C, were highly degraded in $90 \%$ of the evaluated samples stored for 12 months [16].

Although the preparation of gelatin involves heating, in the present study vitamin $\mathrm{C}$ was stable for most of the samples in comparison to other stability studies in the literature $[15,16]$. After 3 days of storage, only 
two samples ( $C$ and $D)$ showed vitamin $C$ concentration below that declared on the label. In these samples, the manufacturer did not practice over-fortification to prevent degradation during preparation and storage, since the levels of vitamin $\mathrm{C}$ in stage 1 were close to that stated on the label. On the other hand, sample $A$, despite showing significant degradation after 3 days of storage, vitamin $C$ content remained above the declared value, probably because in this case, the manufacturer practice over-fortification. This could be verified because the vitamin $\mathrm{C}$ concentration in stage 1 was about $50 \%$ above the declared value (Table I).

Table I. Ascorbic acid concentrations (mg per serving) stated on the nutritional information labels with their respective minimum and maximum tolerance ranges $( \pm 20 \%)$ allowed by law and ascorbic acid contents of the gelatin samples dissolved in cold (stage 1), hot water (stage 2), and refrigerated for three days (stage 3 ).

\begin{tabular}{ccccc}
\hline Sample & $\begin{array}{c}\text { Declared } \\
\text { (acceptable range) }\end{array}$ & $\begin{array}{c}\text { Cold water } \\
\text { (Stage 1) }\end{array}$ & $\begin{array}{c}\text { Hot water } \\
\text { (Stage 2) }\end{array}$ & $\begin{array}{c}\text { Stored for 3 days } \\
\text { in the refrigerator } \\
\text { (Stage 3) }\end{array}$ \\
\hline A & $8.9(7.1-10.7)$ & $13.79 \pm 0.85^{\mathrm{a}}$ & $13.65 \pm 0.79^{\mathrm{a}}$ & $11.50 \pm 0.01^{\mathrm{b}}$ \\
B & $10.0(8.0-12.0)$ & $12.25 \pm 0.97^{\mathrm{a}}$ & $11.32 \pm 1.23^{\mathrm{a}}$ & $10.64 \pm 0.32^{\mathrm{a}}$ \\
C & $8.1(6.5-9.7)$ & $11.33 \pm 0.58^{\mathrm{a}}$ & $6.22 \pm 0.47^{\mathrm{b}}$ & $4.71 \pm 0.70^{\mathrm{b}}$ \\
D & $8.1(6.5-9.7)$ & $8.80 \pm 0.37^{\mathrm{a}}$ & $5.82 \pm 0.31^{\mathrm{b}}$ & $5.41 \pm 0.65^{\mathrm{b}}$ \\
E & $10(8.0-12.0)$ & $11.35 \pm 0.61^{\mathrm{a}}$ & $10.34 \pm 0.13^{\mathrm{a}}$ & $9.05 \pm 0.83^{\mathrm{a}}$ \\
F & $16(12.8-19.2)$ & $24.65 \pm 1.84^{\mathrm{a}}$ & $20.48 \pm 0.74^{\mathrm{a}}$ & $19.63 \pm 3.23^{\mathrm{a}}$ \\
G & $16(12.8-19.2)$ & $22.68 \pm 4.01^{\mathrm{a}}$ & $22.01 \pm 3.73^{\mathrm{a}}$ & $20.83 \pm 0.40^{\mathrm{a}}$ \\
H & $8.9(7.1-10.7)$ & $12.56 \pm 0.72^{\mathrm{a}}$ & $11.55 \pm 2.13^{\mathrm{a}}$ & $11.31 \pm 0.86^{\mathrm{a}}$ \\
\hline
\end{tabular}

$\mathrm{a}$ and $\mathrm{b}$ Means with the same letters for each sample were not significantly different from each other using the Tukey's test at a significance level of $5 \%$.

Several intrinsic and extrinsic factors can affect the stability of vitamin $\mathrm{C}$ such as $\mathrm{pH}$, food matrix composition, ascorbic acid concentration, temperature, and oxygen accessibility. The study of the influence of stability of vitamin $\mathrm{C}$ in apple and carrot purée, considering these factors, showed that extrinsic factors such as oxygen and temperature had the greatest impact on vitamin C stability. However, for the other products, the stability may depend on the food matrix composition [10].

The presence of malic acid as an acidifier in all samples may have contributed to the stability of vitamin C since this micronutrient is more stable in an acid medium [15]. Samples C and D, despite the presence of malic acid, also presented the anti-humectant tricalcium phosphate in the list of ingredients, which may have interfered with the acidity of the product, making vitamin $\mathrm{C}$ more unstable.

The enrichment of foods with vitamins is becoming increasingly common practice to improve their nutritional value. The enrichment process must be careful, as some micronutrients, especially vitamin $\mathrm{C}$, can be easily degraded. Once the enrichment with vitamins is declared on the label, these products must follow the current legislation in relation to the declared and analyzed levels. Resolution RDC $N^{\circ}$ $360 / 2003$ of ANVISA/MS establishes that, for products containing micronutrients in an amount higher than the established tolerance (20\%), the responsible company must keep available the studies that justify such variation [14]. In the case of gelatins, the manufacturer could over-fortify vitamin C, if degradation during preparation and storage could be justified. The values of vitamins declared on the label must be in accordance with the values analyzed in food prepared for consumption. Resolution RDC No 54/2012 of ANVISA/MS, a Technical Regulation on Complementary Nutrition Information, establishes the conditions for the use of the "Source of vitamins" or "Rich in vitamins" attributes, based on the percentage of daily reference intake (DRI) of the nutrient in $100 \mathrm{~mL}$ or $100 \mathrm{~g}$ of finished product or in the portion, that is, the declared nutrient content must be in accordance with that contained in the product ready for consumption. That is why the importance of analyzing vitamin $\mathrm{C}$ after the preparation and storage of gelatin, as this is 
how the population will consume the product.

The Ordinance $N^{\circ} 31 / 1998$ of Health Surveillance Secretariat of the Brazilian Ministry of Health (SVS/ MS) also allows nutrient over-fortification provided this is justified to guarantee the maintenance of the concentration specified on the label [17]. Considering that the analysed products were within shelf life, over-fortification may have been used to maintain the AA levels present until the end of shelf life. In samples that underwent degradation, the manufacturer most likely did not overdose. Due to this, after product preparation and storage, the AA concentrations were below the values stated on the label.

\section{CONCLUSIONS}

All the evaluated gelatin samples were fortified with AA. However, the AA concentrations in $25 \%$ of the samples prepared as recommended and stored for three days were below their declared values. Products having low AA concentrations cannot be labeled with "Source of Vitamin C." In most of the samples, micronutrient overdose may have been performed to maintain the AA concentration stated on the label until the expiration date. The increasing supply of fortified foods in the Brazilian market warrants the need for constant monitoring of these products to ensure that the information available to consumers pertaining to vitamin concentrations in these products is reliable.

\section{REFERENCES}

1. Hameed, A. M.; Asiyanbi-H, T.; Idris, M.; Fadzillah, N.; Mirghani, M. E. S. Trop. Life Sci. Res., 2018, 29 (2), pp 213-227 (https://doi.org/10.21315/tlsr2018.29.2.15).

2. Mariod, A. A.; Adam, H. F. Acta Sci. Pol. Technol. Aliment., 2013, 12 (2), pp 135-147 (http://www.food. actapol.net/issue2/volume/1_2_2013.pdf).

3. IBGE. Instituto Brasileiro de Geografia e Estatística. Available from: http://www.ibge.gov.br/home/ estatistica/populacao/condicaodevida/pof/ [Accessed 18 October 2019].

4. Agência Nacional de Vigilância Sanitária - Anvisa. Resolução RDC № 54, de 12 de novembro de 2012. Dispõe sobre o Regulamento Técnico sobre Informação Nutricional Complementar. Diário Oficial União (Nov. 13 2012).

5. Al-Khudairy, L.; Flowers, N.; Wheelhouse, R.; Ghannam, O.; Hartley, L.; Stranges, S.; Rees, K. Cochrane Database Syst. Rev. 2017, Issue 3. Art. No: CD011114 (https://doi.org/10.1002/14651858. CD011114.pub2).

6. Baghizadeh, A.; Karimi-Maleh, H.; Khoshnama, Z.; Hassankhani, A.; Abbasghorbani, M. Food Anal. Methods., 2015, 8, pp 549-557 (https://doi.org/10.1007/s12161-014-9926-3).

7. Skrovankova, S.; Mlcek, J.; Sochor, J.; Baron, M.; Kynicky, J.; Jurikova, T. Int. J. Electrochem. Sci., 2015, 10, pp 2421-2431 (http://www.electrochemsci.org/list15.htm).

8. Spínola, V.; Llorent-Martínez, E. J.; Castilho, P. C. J. Chrom. A., 2014, 1369, pp 2-17 (https://doi. org/10.1016/j.chroma.2014.09.087)

9. Instituto Adolfo Lutz (IAL). Ministério da Saúde. Agência Nacional de Vigilância Sanitária. Métodos físico-químicos para análise de alimentos, 2005, $4^{\text {th }} \mathrm{Ed}$. p 1018.

10. Herbig, A. L.; Renard, C. M. G. C. Food Chem., 2017, 220, pp 444-451 (https://doi.org/10.1016/j. foodchem.2016.10.012)

11. International Conference on Harmonization (ICH). Validation of Analytical Procedures: Methodology, 1996, Q2B.

12. Equipe Estatcamp. Software Action. Estatcamp - Consultoria em estatística e qualidade. 2014. Available from: http://www.portalaction.com.br [Accessed 18 September 2019].

13. Abe-Matsumoto, L. T.; Sampaio, G. R.; Bastos, D. H. M. J. Food Comp. Anal., 2018, 72, pp 141-149 (https://doi.org/10.1016/j.jfca.2018.07.001).

14. Agência Nacional de Vigilância Sanitária - Anvisa. Resolução RDC No 360, de 23 de dezembro de 2003. Aprova o Regulamento Técnico sobre Rotulagem Nutricional de Alimentos Embalados, tornando obrigatória a rotulagem nutricional. Diário Oficial União (Dec. 26, 2003). 
15. Phillips, K. M.; Council-Troche, M.; Mcginty, R. C.; Rasor, A. S.; Tarrago-Trani, M. T. J. Food Comp. Anal., 2016, 45, pp 147-162 (https://doi.org/10.1016/j.jfca.2015.09.008).

16. Abe-Matsumoto, L. T.; Sampaio, G. R.; Bastos, D. H. M. Braz. J. Pharm. Sci., 2018, 54 (4), pp 1-11 (http://dx.doi.org/10.1590/s2175-97902018000417700).

17. Ministério da Saúde (Brazil) Portaria Nº 31, January 13, 1998. Secretaria de Vigilância Sanitária aprova o Regulamento Técnico referente a Alimentos Adicionados de Nutrientes Essenciais. Diário Oficial da União (Jan. 16, 1998). 